\section{DR. METCHNIKOFF ON MICROBES AND THE HUMAN BODY.}

A SPECIAL meeting of the Manchester Literary and Philo. sopical Society was held on Monday, April 22, when Dr. Flie Metchnikoff, of the Pasteur Institute, Paris, delivered the Wilde Lecture. Before the lecture, the president of the Society (l'rof. Lamb) presented the Wilde Medal for Igor to Dr. Metchnikoff, and the IVilde Premium for Igor to Mr. Thomas Thorp.

Dr. Metchnikuff's lecture, which was in French, was on "La Flore microbienne du Corps humain." Mr. Metchnikoff explained that men were free from microbes at birth, but immediately after birth the surface of the skin and the mucous membranes became peopled with them, and at the end of some days they were numerous and varied. Their germs were derived from the air, or from the water used in washing the child. In summer they developed faster than in winter, and sometimes within four hours after birth there would be found several different sorts of microbes in the intestines. But as a rule their appearance was first observed between the tenth and seventeenth hour after birth. The habitation preferred by the microbes found in the skin was unquestionably the capillary follicles, a kind of deep sheath for the formation of hair. The mucous membranes, the surface of which was always moist and covered with substances by which microbes were readily nourished, were generally supplied with them more abundantly than the skin. The conjunctiva of the eye, however, thanks to its being continually washed by tears, usually rid itself of most of the microbes that found their way into the eye either with the fine clust in the air or through contact with the fingers. There was no doubt that microbes penetrated into the very deepest parts of the respiratory passages, though it was difficult to give a precise account of those ordinarily inhabiting the windpipe, the bronchial tubes and the lungs, since the presence of those which are found there after death might be explained by the in trusion, after death, of microbses from adjacent organs of the body. However that might be, the growth of nicrobes in the lower respiratory passages ought never, in a healthy man, to be great.

It was the digestive organs that exhibited them in the greatest abundance. Dr. Miller, of Berlin, had described more than thirty species inhabiting the cavity of the human mouth, some of them also to be found on the human skin; others, which were found about the teeth, were peculiar to the mouth and were not met with anywhere else. Several of the species characteristic of the mouth made their way deep into the digestive organs and were recognisable in the stomach and the in testines. The stomach, with its acid contents, offered conditions affecting in a glaite exceptional way the development of nicroscopic growths. Many kinds of bacteria could not endure an acid environment; still, the bacterial system of the human stomach was pretty rich, thirty different species having already been distinguished, most of which were not found elsewhere in the digestive system. In the stomach, and still more in the smail intestine, bacilli were the predominating form of microbe, the number and relative proportions of microbes in the small intestine varying with the ford eaten. Meat and vegetable diess respectively stimulated the development of special bacterial forms, though even when the diet was unaltered noteworthy fluctuations in the microbian population were observable. From the smaller intestine the microbes passed to the larger, where they were joined by a great number of new kinds. (Of all the parts of the human budy, the large intestine was undoubtedly the must abundantly teening with these growths. It was inhabited by about forty. five species of micrube, chiefly bacteria, among which bacilli were much the most numerous. The large intestine began to be inhabited immediately after birth. Even on the first day of life, before any food whatever had been taken, a fairly great variety of microbes was to be found there. When the child was suckled the population of the large intestine very soon under. went a change. It became more uniform and was composed mainly, and sometimes almost exclusively, of a particular bacillus. In children fed with the brittle, on cow's mllk, this bacillus was found too, but in smaller numbers, the large intestine in these children being much richer in microbes of various types. After weaning, the abundance of micrubes became nuch greater still. The number of distinct species of microles to be found in a man in health could not be exacily estinated, but quite roughly and provisionally might be put between sixty and seventy.

What could one say of the function of these varied growths? NO. 1643 . VOL. $0_{3}$ ]
Among invertebrate animals there were some covered with much more copious growths than were found on the human skin. On the suuthern and western coasts of England there was found in great numbers a kind of crab whose whole shell was generally covered thickly with vegetable growths. Their use was obvious. They assimilated the crab to the marine vegetation, and made him invisible alike to his enemies and to his prey. No such demonstration could be given of the utility of the microbes on the human skin. On the other hand, the flora of the cavity of the mouth might render man a service. Everybudy had noticed that wounds inside the mouth healed much sooner than those on the outer skin. Moistened by the saliva, the wounds remained in contact with the microbes and their soluble products, which stimulated in a marked degree the reaction of the human organism. The secretions of the microbes attracter? a great number of white blood-corpuscles, which cleaned the wound, cleared it of microbes and mortified tissues, and so favoured the process of recovery. In the lower parts of the digestive system this function of microbes was less important, the mucous membrane there being much more seldom torn. But it was proballe that the acids secreted by many bacteria in the small intestine rendered a real service by preventing the development of certain other microbes which might impede digestion. This preventive function was manifested also in the course of conflict between the human organism and microbes of a iery dangerous kind, and there was reason to believe that in some cases the germs of Asiatic cholera were rendered innocuous by the action of the microbes which they encountered in the intestines. It had also been contended by some authorities that the microbes in the digestive system played an important part in the digesting of food, and that without them food could not be assimilated; but the data available would lead rather to the general conclusion that for the normal action of the human digestion the presence of the intestinal microbes was by no means indispensable.

They should now try to ascertain whether the microbes in the human systen might injure its health. When the defensive forces of the body Hagged, whatever might be the reason, the microbes on the skin began to multiply and to pour their noxious products into the tissues and the blood. It often hap. pened that serious boils and anthrax developed themselves in persons suffering from diabetes or some other general disease, their cause being, not the introduction of a morbid germ from without, but the excessive multiplication of certain microbes which are found in the healthy human skin and which now took advantage of the enfeeblement of the defensive cells. But the greatest harm was done by the microbes of the stomach and intestines. It had been recognised that the gravity of the danger incurred in cases of perforation of the intestines was due to the intlammatory action of the microbes that escaped into the peritoneum. Nor was the injurious effect restricted to cases where the microbes penet rated directly into the other organs or into the blood, for the microbes produced soluble substances which could be absorbed through the wall of the intestines and so make their way into the circulation. Several of these were substances more or less poisonous ín their action, and it was very probable that a great many of these toxic products of our intestinal fiora had still to be ascertained. In spite of our imperfect knowledge, there was reason to state, with the greatest strength of conviction, that the poisons produced by the intestinal microbes played a considerable part in causing many and various maladies. Headaches, exhaustion, neurasthenia, dyspeptic asthma, certain forms of epilepsy, several skin diseases, including acne, had by certain authorities been attributed wholly or in part to the action of poisons originated in the digestive system. Even in cases of mental disease its importance could not be denied; it had a noteworthy connection with diseases involving atrophy of the higher organs, such as the brain, the heart, the kidneys and the liver.

Dr. Metchnikoff then discussed at some length the relations of the normal microbian population of the human body-that is, the microbes present in it in a state of health-and the pathological microbes, or microbes directly inducing specific disease. He pointed to the methods practised in medicine and surgery to limit or counteract the action of microbes ascertainedly or potentially generative of disease, and to what he believed to be limitations to the beneficial operation of antiseptics. There was a tendency to renounce more or less completely the use of antiseptics, and to have recourse more and more to simply mechanical measures for keeping microbes out of the body-the prolonged washing of the hands, for instance, or the moistening 
of the conjunctiva of the eye and other mucous membranes with liquids not strong enough to injure the living cells of the skin. The best method of antiseptic treatment of the intestine, merely relative as its efficacy might be, was now recognised in the use of drugs which produced irequent and abundant evacuation.

How were we to square the conviction that so many of the microbes usually found in the body were injurious with the argument, drawn from the work of Darwin, that if our nicrobes are so dangerous they ought long ago to have been eliminated simply by the operation of natural selection? One observed constantly that not merely natural characteristics unfavourable to their possessor's life, but even organs which had merely ceased to be useful to him, disappeared more or less completely. To bring out more clearly this paradoxical aspect of the survival of our microbes, most of which were not merely useless but unquestionably injurious, he would draw attention to the fact that the very organs of the body which sustained this flora were themselves for the most part either useless or injurious to health and life. They would remember that the ducts of the capillary follicles in the skin were the seat of a microbian vegetation often composed largely of microbes capable of producing more or less serious disease. Well, those follicles were useless organs, and represented merely what was left of the hair that covered the skin of animals who were our ancestors. In the digestive apparatus of man, the part of the body richest in microbes, there were also to be found parts which, to say' the least of them, were now useless. The vermiform appendix, for instance, was the remains of an organ which was more fully developed in our animal forefathers; in the anthropoid apes it was already found in the process of reduction. Even the stomach, that organ which might seem so indispensable for digestion and the normal existence of man, was in reality nothing but a large reservoir for food, a reservoir which could without serious inconvenience be dispensed with. There were at that moment four persons living without stomachs, and thus furnishing a strong argument against the utility of that organ.

Of all the parts of our digestive system it was certainly the small intestine alone that was indispensable to the continuance of life. And yet in man, who could support himself on food easily digestible, the small intestine was disproportionately fully developed. Instead of having it between 18 and 21 feet long, man might do with one-third of that length. Kukula reported a case in which he had removed almost two-thirds of the small intestine with the greatest advantage to the patient. In one case Körte had removed, together with part of the small intestine, the greater part of the large intestine, leaving only the terminal section. As a result of this operation the patient had been completely cured. He could cite other cases of successful surgical operations to prove the uselessness of the large intestine to human beings. In one case the whole of the large intestine had atrophied of itself, without operation, in consequence of a fistula, without interfering with the active life of the subject. The sum of all this was that we possessed a voluminous and highly developed organ, the large intestine, which fulfilled no useful function and bred a very copious and varied mass of microbes, capable of injuring us through their poisons.

In face of thisf act it remained to ask what the large intestine was, what its origin and the reason of its existence. The history of the capillary follicles was comparatively simple, for they were the surviving traces of hair which had protected from the cold the animals from which man was descended. The large intestine, on the contrary, was no mere relic, but an organ highly developed. It was, as a rule, found only in the mammiferous animals, and not in birds, reptiles, or others of the lower vertebrates. Dr. Metchnikoff went on to trace in some detail the development of the large intestine to the prevalence of certain special conditions in the life of herbivorous vertebrate animals capable of running at great speed, conditions no longer present in the life of their descendants, and no longer calling for the peculiar organisation developed to meet them. The slow tendency of evolution to bring about the atrophy of such organs or characteristics might, however, be assisted by medicine and surgery, medicine coping more effectually with the noxious microbes and their effects, while the progress of sur gery had already brought it within its power to remove by operation organs or parts of organs propitious to the growth of the "flora."

Dr. Schunck proposed, and Prof. Hickson seconded, a vote of thanks to the lecturer, and the resolution was carried by acclamation.

No. 1643 , voL. 63$]$

\section{MODERN METHODS OF GAS MANUFAC- TURE.}

A PAPER on motlern practice in the manufacture and distribution of illuminating gas was read by Mr. Harry E. Jones at the meeting of the Institution of Civil Engineers on April I6, and some of the points dealt with are here summarised.

The author remarked that improved returns from residuals at gasworks have been obtained by giving greater attention to the saving of fuel by the use of generator furnaces; by manufactur . ing the ammonia at the gas-works; by the preparation of cyanogen; and by the more extensive application of the antiseptics which are largely and cheaply produced from the tar.

The enrichment of gas, by reducing the return from residuals, has adversely affected the progress of gas-supply. The materials needed are all costly, and yield no return. Moreover, with incandescent burners, the cost of enrichment is wasted. Of the means of enrichment available, carburetted water-gas is preferred for cheapness and permanency. The advantages of this method are : facility for rapid and considerable addition to the output of gas, and for suspension of such additional supply without consequent expense; complete control of illuminating power over a wide range ; avoidance of excessive accumulation of coke in winter; prevention of the deposit of naphthalene in the distributing mains and services, which formerly caused great loss and inconvenience; and reduction of space required by the plant, and for storage of materials. It was pointed out, however, that it is chiefly for mid-winter use, to relieve the strain on the coal-gas plant and the drain on the collieries, and to meet fogs and sudden climatic changes, that the system is profitable, as the price of oil advances with the price of coal, and to a figure that, having regard to value of residuals, cannot be paid without loss. During the winter of 1900-1901 the price of oil was practically prohibitive of its use, except for necessary enrichment or emergency use. Should it, however, be possible to supply unenriched water-gas, which, with the Welsbach burner, gives equal illuminating power, then the use of oil could be dispensed with and the combined coal- and water-gas processes could be carried on with a large saving and would enable the price of gas to be lowered by between Is. $2 d$. and is. $8 d$. per I000 cubic feet.

In purifying-plant the author recommended the abandonment of the old hydraulic seal, which is unstable, costly and very perishable. In his practice the entire cover is removable, being very light and held down by small holts at the margin, and by bolts passing through both cover and floor and spaced at equal distances. The vessels are 8 feet deep and are arranged in groups of five worked in ordinary sequence, having both lime and oxide of iron in each. This system fulfils without nuisance all the requirements of the sulphur-purification demanded by the London Gas Referees without the cost, risk and space of the system of three separate groups previously necessary, in order, for carbonic acid, carbon bisulphide and sulphuretter hydroger. For condensers the author prefers horizontal tubes, in which the tar and gas are cooled together, which have been found to remove naphthalene. Coke scrulbers are simplest and cheapest, and in practice more than secure the degree of purification from ammonia exacted by the London Gas Referees, and, l,y the ammonia retained, purifies the gas also from carbonic acid and sulphur. The residuals of gas are useful in purification, and a cycle of reactions was traced in the processes of manufacturing sulphate of ammonia by sulphuric acid made partly from the sulphur in the ammoniacal liquor and partly from that in the residual spent oxide of iron from purifiers.

The pressure for distribution of gas is usually 3 inches to 4 inches head of water, but Mr. C. C. Carpenter has for some time been delivering by means of Sturtevant fans, at pressures between 12 inches and 18 inches. In America distribution has been accomplished over long distances by employment of pressures of several pounds per square inch. Service pipes are now laid in steam-tubing 30 per cent. thicker than gas-tubing; they are coated with pitch before filling the ground in, and their life has thus been extended from i 2 years or 14 years to more than 20 years. Meters of the "dry" form are now invariably employed, which, if examined periodically, at intervals of 6 or 8 years, can be maintained fairly accurate; by improvements in manufacture their life has been increased from 12 years to nearly 20 years. 